\title{
Review \\ The Role of IL-17-Producing Cells in Cutaneous Fungal Infections
}

\author{
Yu Sawada *, Ayako Setoyama, Yumiko Sakuragi, Natsuko Saito-Sasaki, Haruna Yoshioka \\ and Motonobu Nakamura
}

Citation: Sawada, Y.; Setoyama, A.; Sakuragi, Y.; Saito-Sasaki, N.; Yoshioka, H.; Nakamura, M. The Role of IL-17-Producing Cells in Cutaneous Fungal Infections. Int. J. Mol. Sci. 2021, 22, 5794. https:// doi.org/10.3390/ijms22115794

Academic Editor: Juan Francisco Martín

Received: 24 April 2021

Accepted: 25 May 2021

Published: 28 May 2021

Publisher's Note: MDPI stays neutral with regard to jurisdictional claims in published maps and institutional affiliations.

Copyright: (c) 2021 by the authors. Licensee MDPI, Basel, Switzerland. This article is an open access article distributed under the terms and conditions of the Creative Commons Attribution (CC BY) license (https:/ / creativecommons.org/licenses/by/ $4.0 /)$.
Department of Dermatology, University of Occupational and Environmental Health, Iseigaoka, Yahatanishi-ku, Kitakyushu, Fukuoka 807-8555, Japan; ayako-s@med.uoeh-u.ac.jp (A.S.); y-sakuragi@med.uoeh-u.ac.jp (Y.S.); natsuko-saito@med.uoeh-u.ac.jp (N.S.-S.); haruna-yoshioka@med.uoeh-u.ac.jp (H.Y.); motonaka@med.uoeh-u.ac.jp (M.N.)

* Correspondence: long-ago@med.uoeh-u.ac.jp; Tel.: +81-093-691-7445

\begin{abstract}
The skin is the outermost layer of the body and is exposed to many environmental stimuli, which cause various inflammatory immune responses in the skin. Among them, fungi are common microorganisms that colonize the skin and cause cutaneous fungal diseases such as candidiasis and dermatophytosis. The skin exerts inflammatory responses to eliminate these fungi through the cooperation of skin-component immune cells. IL-17 producing cells are representative immune cells that play a vital role in anti-fungal action in the skin by producing antimicrobial peptides and facilitating neutrophil infiltration. However, the actual impact of IL-17-producing cells in cutaneous fungal infections remains unclear. In this review, we focused on the role of IL-17-producing cells in a series of cutaneous fungal infections, the characteristics of skin infectious fungi, and the recognition of cell components that drive cutaneous immune cells.
\end{abstract}

Keywords: IL-17; Th17; antimicrobial peptide; fungal infection; skin

\section{Introduction}

The abundance of environmental stimuli is constitutively surrounding human body. The skin is an organ located in the outermost layer of the human body. Because of this characteristics, the skin is easily exposed to various external environmental stimuli [1,2], such as ultraviolet light, chemicals, and allergens in daily life [3-5]. Among these environmental factors, microorganisms are representative external environmental agents that exert both harmful and beneficial effects on human skin health. Streptococcus aureus and Propionibacterium acnes are major colonizing microorganisms in the epidermis and exhibit virulence to exacerbate cutaneous inflammatory disease, whereas some microorganisms have a beneficial impact on the skin [6]. Therefore, the knowledge of these microorganisms on the skin is important for clinicians.

Fungi are a group of eukaryotic organisms including yeasts, and are capable of infecting human skin with immunocompromised hosts, resulting in the development of fungal skin diseases [7]. Fungal infections are localized on the skin surface and hair follicles; they are sometimes insensitive to current treatment because of their characteristics of invasive and persistent infection facilitated by the immunosuppressive action of their cell components [8].

The skin exerts immune reactions to defend against external environmental stimuli [9]. Although fungi colonize the epithelial surface, keratinocytes, the main epidermal component cells, drive inflammatory reactions after the recognition of specific pattern of the pathogens. The skin counters harmful microorganisms through the interaction of various cells in the skin by neutrophil infiltration, epidermal proliferation, and antimicrobial peptide production for host protection [10]. Further, dermatophytes initiate an adaptive immune response that protects against re-infection [11]. To exert antimicrobial action 
against microorganisms in the skin, various cells cooperate to promote bactericidal action using different approaches to eliminate skin-colonized microorganisms. Among these cells, Th17 cells secrete IL-17 and IL-22 for enhancing antimicrobial peptide production and immune cell function against microorganisms. IL-17 cytokines play a vital role in the cutaneous host defense against microorganisms such as fungi [12]. In human dermatophytosis, exacerbation of skin infection has been observed in patients with a deficiency of the IL-17 pathway [13]. Because of the current development of cytokine-targeted treatment, IL-17targeted treatment has also demonstrated the importance of IL-17 in the skin. For instance, treatment with anti-IL-17 antibody results in a high frequency of superficial fungal infection in the skin, which sometimes becomes intractable with topical antifungal treatment.

A limited number of reports have explored the contribution of IL-17 to fungal skin infection. Thus, the detailed mechanisms underlying the beneficial effects of IL-17 on a series of skin fungal infections remain unclear. In this review, we focused on the involvement of IL-17-producing cells in the skin in the pathogenesis of cutaneous fungal infection. For a better understanding of immune reactions in each series of cutaneous fungi, we also mentioned the importance of fungal cell components, which are recognized by immune cells and are responsible for the development of immune responses against cutaneous fungal infections.

\subsection{Th17 Cells and Antimicrobial Action against Fungi}

Inflammatory diseases such as rheumatoid arthritis, psoriasis, and inflammatory bowel disease are sometimes exacerbated by lymphocytes [14-17]. IL-17-producing cells are related to inflammation induced by the synergistic effect of certain inflammatory cytokines, including IL-23 and TNF- $\alpha$, and antigen-presenting cells, following the upregulation of transcription factor ROR $\gamma \mathrm{t}$ [18]. In the development of IL-17-producing CD4 $4^{+}$cells, TGF- $\beta$ and IL-6 are required for the differentiation from naïve T cells [19]. This developmental axis overlaps with Treg. While the origin of Th17 differentiation is intrinsically linked with Treg due to their common requirement of TGF- $\beta$ signaling, Th17 differentiation also require IL-6 signaling [19].

IL-17-producing cells are recognized in Th17, Tc17, and $\gamma \delta$ T cells. Th17 cells are the main source of IL-17 in human skin and has been identified the pathogenetic role in various inflammatory skin diseases, such as atopic dermatitis and psoriasis [20,21]. In addition, $\mathrm{CD}^{+}$cells are abundantly increased in the lesional inflammatory skin, and these cells produce IL-17, namely Tc17 [22-24]. $\gamma \delta \mathrm{T}$ cells are the main source of IL-17 in mice involved in the pathogenesis of inflammatory skin diseases, especially psoriasis [25-29].

IL-17 plays a vital role in host defense against microorganisms through the production of antimicrobial peptides to promote microbial homeostasis and neutrophil recruitment [30] (Figure 1). Consistently, dysfunction of IL-17 signaling is closely associated with increased morbidity during microbial infection [31]. Predisposing host immune conditions, such as epithelial barrier disruption and cutaneous inflammation of the skin in atopic dermatitis, are closely related to the pathological function of commensal fungi-specific Th17 cells [32].

IL-17 drives IL-8 mediated neutrophil migration and antimicrobial peptide production, such as cathelicidin and human $\beta$-defencins (HBDs) by keratinocytes, which are impaired by Th2 cytokines.

\subsection{Pattern Recognition for IL-17 Induction against Fungi}

The fungal cell wall is composed of three component matrices: Mannans, glucan, and chitin [33] (Figure 2). The outer layer consists of mannans such as O-linked and $\mathrm{N}$-linked mannose polymers. In contrast, chitin is placed at the innermost layer of the cell wall and is connected with $\beta$-glucan to establish hydrogen bonds for constructing an inner layer network of microfibrils. Host innate immunity requires pattern recognition receptors (PRRs) to induce an immune response against fungi, namely pathogen-associated molecular patterns (PAMPs) (Figure 2). Four major PRRs have been identified: C-type lectin receptors (CLRs), Toll-like receptors (TLRs), retinoic acid-inducible gene I (RIGI)-like 
receptors (RLRs), and nucleotide-binding oligomerization domain (NOD)-like receptors (NLRs). TLR2, TLR4, and TLR9 can recognize phospholipomannan (PLM), and TLR7 is a receptor for single-stranded RNA, which is an intracellular component of fungi [34]. TLRs exhibit important signaling adaptors, such as MyD88 and TRIF. MyD88 combines almost all TLRs to drive downstream pathways, including NF- $\mathrm{kB}$. Recent studies have revealed that the receptor for chitin, a cell wall component, contributes to the suppression of inflammatory responses. Further, inflammatory cytokine production is suppressed by FIBCD1-mediated mechanisms in lung epithelial cells [35]. Epithelial cell-specific FIBCD1-transgenic mice showed decreased fungal infection and impaired fungal-driven inflammatory responses in the intestine [36].

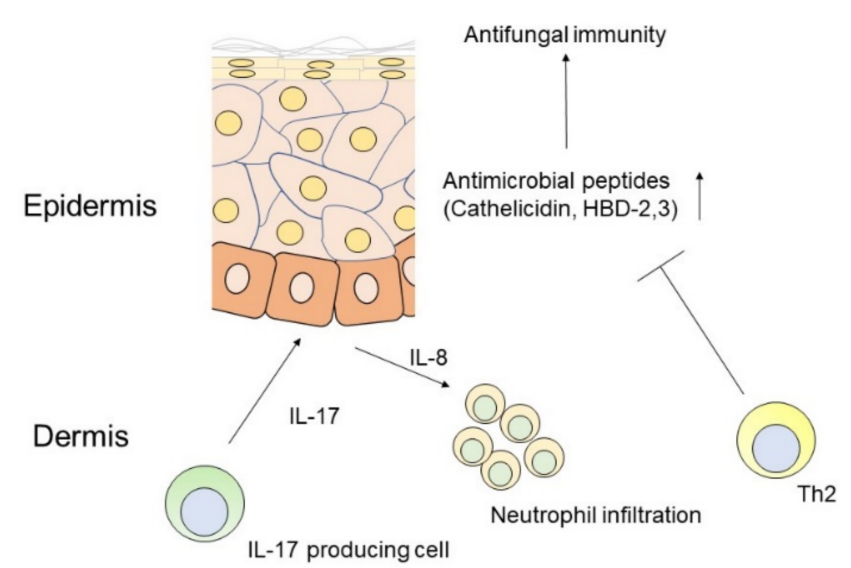

Figure 1. Scheme of antifungal immune responses mediated by IL-17 in the skin.

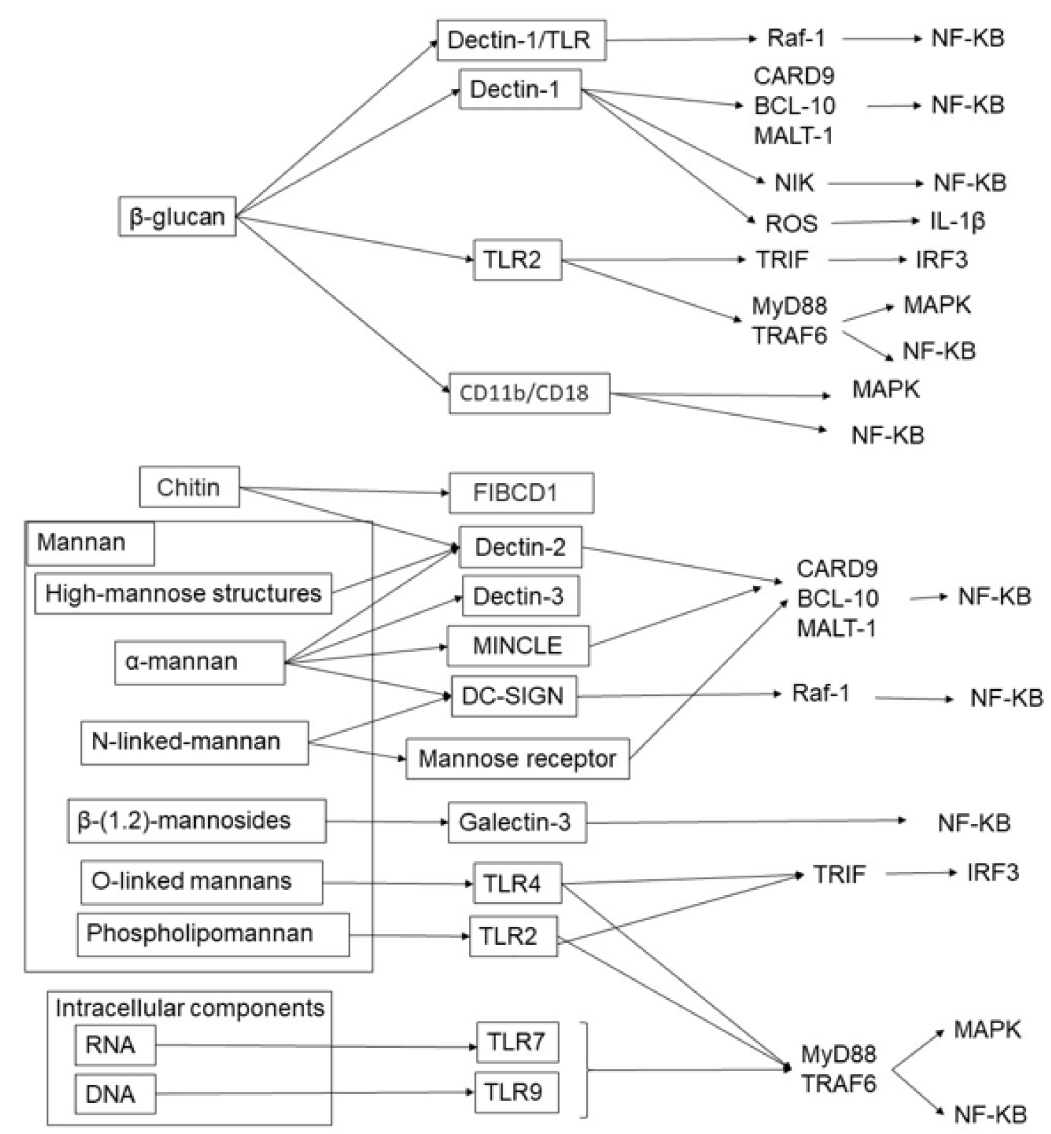

Figure 2. Fungal cell components and their receptors in humans. 
The cell components are mainly divided into cell walls and intracellular components, and there are various pattern recognition receptors and their downstream signaling pathways. The cell wall is composed of glucan, mannan, and chitin, and the intracellular components are RNA and DNA. These components drive specific pattern recognition receptor-mediated inflammatory immune responses.

PAMPs also enable the initiation of IL-17-producing cell development. For example, deficiency in the adaptor TRIF, which is downstream of TLR signaling, results in failure of IL-17-producing cell development in response to fungal infection. Dectin-1 is a receptor for $\beta$-glucan and can activate IL-17 production. In the skin, Langerhans cells recognize fungal pathogens, which drive TLR/MYD88 and dectin-1-dependent pathway and subsequently produces IL-6 mediated IL-17-producing cell development [12,37]. Blockages of IL-17 and IL-23 reduce chemokine and antimicrobial expression, and increase the risk of systemic fungal burden [38,39]. Therefore, it is assumed that humans have developed immune reactions against fungal cell components to eliminate infection and as the host immune response, and that IL-17 plays a vital role in the host defense against fungal infection.

\subsection{IL-17 and Antimicrobial Action in the Skin}

The main sources of antimicrobial peptides in human skin are keratinocytes, sebocytes, eccrine epithelial cells, mast cells, and neutrophils. Keratinocytes produce various antimicrobial peptides such as human $\beta$-defensins (hBDs), LL-37, psoriasin, RNase, lactoferrin, lysozyme, SLP, elafin, $\alpha-\mathrm{MSH}$, catestatin, and calprotectin. hBDs and LL-37 are also produced by eccrine epithelial cells, sebocytes, and mast cells. These antimicrobial peptides, especially defensins and LL-37 are produced in response to signal mediated by pattern recognition receptors, such as TLRs. Among antimicrobial peptides, hBD-2, hBD-3, LL-37, and psoriasin are activated by IL-17-mediated inflammatory responses. For instance, topical application of a vitamin D analog decreases hBD-2 and hBD-3, accompanied with reduced IL-17 in patients with psoriasis [40]. Further, IL-17A enhances vitamin-D-mediated LL-37 expression in keratinocytes in vitro [41]. Keratinocytes in atopic skin upregulate hBD-2 in response to IL-17 [42]. IL-17A enhances transcript expression of S100A7/psoriasin in human keratinocytes [43]. However, these antimicrobial peptides have limited expression under Th2-predominant skin conditions with co-expressed IL-4/IL-13, despite the presence of sufficient IL-17 production in the skin [42]. This inhibitory action against antimicrobial peptides explains the preferential colonization of the skin in atopic dermatitis with S. aureus and fungal infections, despite increased IL-17 production in the skin.

\subsection{Skin Fungal Infection and Th17 Cells}

Because the skin is the largest surface and an open field for the external environment in the human body, various microorganisms are transmitted from the external environment and from other humans and/or animals with easy access to the skin. To gain a better understanding of the role of IL-17-producing cells in host defense against cutaneous fungal infection, we have summarized the characteristics and pathogens of each series of cutaneous fungal infections and the actual impact of IL-17-producing cells.

\section{Candidiasis}

Candidiasis is a fungal infection by Candida species that is localized on the skin and mucosal surfaces; it is characterized by white patches on the tongue or other areas of the mouth and throat. Under immune-compromised host conditions, candidiasis becomes invasive and spreads to systemic organs. The cell wall of Candida sp. mainly consists of chitin, glucans, and mannans. Among them, mannans and mannoproteins are the most important for activating host defense. Other polysaccharides in Candida albicans (C. albicans), such as glucans and chitin, are much less immunogenic than mannans [44]. Mannans also induce immunosuppressive action by enhancing Treg function [45]. C. albicans-derived $\beta$-glucan exacerbates inflammatory cytokine production in macrophages by Dectin-1/TLR2 [46,47], SCARF1 [48], and CD36 [48]. In addition, mannan in C. albicans is recognized by TLR2 [49], 
TLR4 [47], mannose-binding lectin [50], galectin-3 [51], Dectin-2 [52], Dectin-3 [53], DCSIGN [54], and mannose receptor [55]. The intracellular components of $C$. albicans such as RNA and DNA, are also recognized by TLR7 [34] and TLR9 [56], respectively.

In mouse skin, $\gamma \delta \mathrm{T}$ cells are the major source of IL-17A [26,27]. These cells are also induced under invasive $C$. albicans infection and are required for resistance against pathogens [57]. CD301 $\mathrm{b}^{+}$dermal dendritic cells are required for the IL-17A induction from dermal $\gamma \delta \mathrm{T}$ cells, and resistance to C. albicans requires IL-23 production. Sensory neurons are also involved in these mechanisms, and depletion impairs the elimination of C. albicans [57]. Candida-specific TCR transgenic mice reactive to Candida-derived endogenous antigens access the draining lymph nodes and are directly presented by migratory dendritic cells [58]. IL-17 is increased during the initial phase of cutaneous infection and is correlated with the rapid elimination of $C$. albicans. Inhibitory cytokines such as IL-10 and TGF- $\beta$ are increased in the later phase and prevent exacerbation of inflammation in the skin [59]. In mice, $\gamma \delta \mathrm{T}$ cells are the main IL-17-producing cells in the initial phase after $C$. albicans infection; in the later phase, IL-17 production gradually shifts to the predominant $\alpha \beta$ Th17 effector T cells. Afterward, the majority of $C$. albicans-reactive IL-17-producing $\mathrm{T}$ cells become tissue-resident memory $\mathrm{CD} 4^{+} \mathrm{T}$ cells. These $\mathrm{CD} 4^{+} \mathrm{T}$ cells acquire CD69 and CD103 expression for localization to the papillary dermis [60].

It has also been reported that IL-17 is essential for anti-fungal immunity mediated by the pattern recognition in human. An autosomal recessive form of susceptibility to chronic mucocutaneous candidiasis is associated with homozygous mutations in CARD9 [61,62]. Recurrent fungal infection is observed with CARD9 mutation, which is related to reduced Th17 cells. CARD9 deficiency results in an impaired immune response mediated by Dectin-1 [62]. Autosomal recessive deficiency of interleukin-17 receptor A (IL-17RA) and autosomal dominant deficiency of the cytokine interleukin-17F (IL-17F) impairs the responses to IL-17A and IL-17F. In contrast, IL-17F deficiency partially displays antifungal activity [63]. Autoimmune polyendocrinopathy-candidiasis-ectodermal dystrophy (APECED) with chronic mucocutaneous candidiasis shows neutralizing autoantibodies against Th17 cytokines and significant defects in IL-17F and IL-22 production [64]. Chronic mucocutaneous candidiasis with autosomal recessive IL-17RC deficiency leads to impaired cellular responses to IL-17A and IL-17F [65]. Signal transducer and activator of transcription 1 (STAT1)-gain-of-function mutations or heterozygous missense mutations in STAT1 result in severely impaired Th17 responses [66,67]. Impaired Th17 is also observed in patients with loss-of-function STAT3 mutations (autosomal dominant hyper-IgE syndrome; AD-HIES) with recurrent oral fungal infections [68].

\section{Dermatophytosis}

Dermatophytosis is a fungal infection of the skin that is typically caused by Trichophyton, Microsporum, and Epidermophyton species. It often causes ring-form scaly erythematous skin, particularly with Microsporum species. Healthy subjects are also at the risk of infection due to contact sports and obesity. The cell wall of Trichophyton is enriched in mannan, which can activate immune reactions by itself [49]; in contrast, mannan from the cell wall of Trichophyton rubrum has the potential to inhibit cell-mediated immunity and keratinocyte proliferation $[69,70]$.

Superficial dermatophytosis presents in the stratum corneum and cannot directly make contact with immune cells in the dermis. Therefore, some possible anti-fungal immune responses have been postulated [69]. In humans, an increased number of Th17 cells is observed in the peripheral blood and skin of patients with dermatophytosis [71,72]. Consistently, innate immune disrupted diseases, such as adult-T cell leukemia/lymphoma (ATLL), commonly exhibit superficial dermatophytosis among cutaneous mycotic infections [73]. The frequency of Th17 cells in peripheral blood is reduced in patients with ATLL [74]. Further, the epidermal expression of hBD-2, LL-37, and S100A7/psoriasin is decreased in patients with ATLL and dermatophytosis [74,75], indicating that the secretion of 
Th17-mediated antimicrobial peptides by keratinocytes is reduced, leading to the frequent occurrences of dermatophytosis.

In an animal model of superficial skin infection with Microsporum canis, mild inflammation in the skin was observed with a Th17-mediated immune response by Langerin ${ }^{+}$ cells [76]. IL-17 deficiency allows $M$. canis to colonize the epidermis and exacerbate skin inflammation through an IFN- $\gamma$-mediated response. Dectin- 1 and Dectin- 2 deficiency result in inadequate production of inflammatory cytokines in response to T. rubrum infection and impair its elimination [77]. In addition, mice lacking IL-1R show decreased IL-17 production in response to T. rubrum [78]. STAT1 gain-of-function mutation also facilitates severe dermatophyte infection in the skin with impaired Th17 responses in the peripheral blood [66].

\section{Malassezia}

Malassezia is localized on the skin surface of many animals including humans. Representative clinical skin diseases include pityriasis versicolor and Malassezia folliculitis. In pityriasis versicolor, Malassezia species, especially Malassezia globosa, can cause hypopigmentation or hyperpigmentation on the trunk and other regions of the human body. Malassezia folliculitis is often observed in adolescents and is characterized by follicular erythematous papules localized on the chest, back, and upper arms. Malassezia species have $\beta$-glucan-enriched cell walls [79], and drives responses mediated by TLR2 [80], Dectin1 [81], Dectin-2 [81], MINCLE [82], mannose receptor [83], and TLR9 [84].

$\mathrm{T}$ cells in the peripheral blood and skin of patients with atopic dermatitis sensitized to Malassezia secrete IL-17 and IL-22 [85], possibly due to autoimmunity and cross-reactivity between a fungal antigen and human thioredoxin. Malassezia metabolites also enhance the expression of IL-36 $\gamma$ in human epidermal keratinocytes in vitro, which induces IL-17 production [86].

In an experiment with mice, IL-17A and IL-22 induction is observed in response to M. pachydermatis-colonized skin, which prevented fungal growth on the skin [87]. Further, inhibition of the IL-23/IL-17 axis was found to impair Malassezia-specific immunity in the skin and to disrupt the fungal clearance mediated by CARD9 or MYD88.

\section{Sporotrichosis}

Sporotrichosis is a disease caused by Sporothrix schenkii (S. schenckii) and usually affects the skin. Because this species exists naturally in soil and plants, it usually affects agricultural workers and enters through small skin wounds to cause infection $[88,89]$. Sporotrichosis growth is relatively slow, and a long time is required for the first symptoms to appear, about 1 to 12 weeks after the initial exposure to S. schenckii [90]. Immune-compromised hosts sometimes develop serious complications that can spread to systemic organs. The cell wall of S. schenkii is recognized by Dectin-1 [91] and TLR4 [92] in macrophages and by TLR2/4 in keratinocytes [93].

S. schenckii activates different immune profiles during host defense. Upon subcutaneous injection, S. schenckii enhances IL-17 production [94]; however, this peak gradually decreases in the later phase [95]. Dectin-1 and IL-17 are not essential for S. schenckii clearance, suggesting that different molecular recognition pattern of $S$. schenckii might be targeted to exert antifungal action in cutaneous immunity [95].

Systemic dissemination of $S$. schenckii by intraperitoneal administration results in an enhancement of Th17 response [96]. Neutralizing IL-23 antibody treatment, which blocks downstream IL-17 production, is closely associated with an impaired capacity to control $S$. schenckii infection [96]. While fungal loads are increased by anti-IL-23 antibody treatment, this does not affect survival against infection. Th17 is essential to eliminate $S$. schenckii infection in the initial phase, but not for survival against $S$. schenckii infection.

The NLRP3 inflammasome is related to the innate immune recognition of S. schenckii to exert an adaptive immune response for protection against infection [97]. The NLRP3 inflammasome appears to be critical for IL-17 release. NLRP3 deficiency results in susceptibility 
to infection, suggesting that NLRP3-mediated responses contribute to the development of host protection against $S$. schenckii infection. Furthermore, S. schenckii-induced IL-17 production is a TLR2 independent mechanism, and the absence of a Th1 response in TLR2 deficiency is concomitant with IL-17 production [98].

\section{Chromoblastomycosis}

Chromoblastomycosis is a chronic fungal infection in the subcutaneous tissue and is most commonly observed in tropical climates; it is caused by Fonsecaea monophora, Fonsecaea pedrosoi (F. pedrosoi), Phialophora verrucosa, and Cladophialophora carrionii. Chromoblastomycosis is caused by various fungal infections in subcutaneous lesions, and its clinical prognosis is not favorable without treatment. In contrast, it is intractable and persistent with the current treatments. Chromoblastomycosis pathogens activate TLR2/4 [99], NLRP3 [100], Dectin-1 [101], Dectin-2 [102], and MINCLE [101]. The pathogen component chitin suppresses the Th1 immune response [103].

Chromoblastomycosis in human skin shows high expression of IL-17 [104]. In an experimental chromoblastomycosis infection animal model, F. pedrosoi hyphae-injected skin shows that $\mathrm{T}$ cells are skewed into Th17-and Th1 dominant phenotypes [102]. Th17 cells are increased in the injected skin lesion during the early phase, followed by a Th1 dominant condition in the later phase. IL-17-neutralizing treatment decreased fungal elimination. In contrast, the cell wall of a chitin-like pathogen component in chromoblastomycosis suppresses IL-17 via Dectin-1 [105]. In addition, a recent study identified that the nonrecognition of $F$. pedrosoi by TLR might also play a role in the defective production of proinflammatory cytokines [106]. This might be involved in the pathogenesis of chronic infections in chromoblastomycosis.

\section{Mycetoma}

Mycetoma is a chronic subcutaneous infection by eumycetoma fungi, especially Madurella mycetomatis and Medicopsis romeroi, which infiltrate the body through the skin surface, and is commonly observed in the foot; it is characterized by a subcutaneous solid mass and eventually invades the underlying bone. Pseudallescheria boydii is also a mycetoma pathogen and is recognized by TLR2 [107] and TLR4 [108], to produce proinflammatory cytokines in macrophages.

However, these findings do not reflect the actual impact of IL-17 resistance against mycetoma. Immune responses such as antimicrobial peptides may not be effective against mycetoma. Consistently, a previous study showed that hBD2 expression could not be detected in the skin of patients with mycetoma [109], suggesting that some innate immunity dysfunction might be the reason underlying chronic mycetoma infection, despite sufficient IL-17 production in the skin.

\section{Paracoccidioidomycosis}

Paracoccidioidomycosis is an acute to chronic fungal infection caused by Paracoccidioides species, especially Paracoccidioides brasiliensis (P. brasiliensis) and Paracoccidioides lutzii. It is commonly observed in areas of Central and South America. Paracoccidioidomycosis is characterized by ulcers and granulomatous lesions on the skin, which generally occur several weeks or months to years after the initial exposure to the fungus. Pathogens of paracoccidioidomycosis are recognized by TLR9 [110], TLR4 [111], TLR2, 4, Dectin-1 [112], DC-sign [113], and Galectin-3. Galectin-3-deficient macrophages exhibit higher TLR2 transcript levels and IL-10 production than wild-type macrophages after stimulation with P. brasiliensis antigens [114].

In vitro analysis indicated that $P$. brasiliensis-infected antigen presentation cells undergo Th17 differentiation mediated by Dectin-1 [115], TLR4 [115], NLRP3 [116], and IFN- $\beta /$ Caspase11/IL-1 $\alpha$ [117]. Antigen presenting cells also require IDO1 for Th17 differentiation [118]. Further, IDO1-deficient mice show decreased their survival after intratracheal injection of P. brasiliensis. 
Few studies have focused on the cutaneous infection of Paracoccidioides. Paracoccidioidomycosis shows epidermal hyperplasia and well-organized granulomas with a high frequency of IL-17-expressing cells [119]. Intratracheal injection of P. brasiliensis infection promotes the IL-17 production in the lung in a Myd88-dependent manner [120]. Paracoccidioides infection in the lung induces IL-17 production mediated by Dectin-1 [121], Caspase $11, \mathrm{IL}-1 \alpha$ [117], and NALP3 (NLRP3) [122], which are required for fungal clearance. Thus, IL-17 is responsible for anti-fungal action against Paracoccidioides infection; however, the related cutaneous immune responses are largely unknown.

\section{Coccidioidomycosis}

Coccidioidomycosis is a fungal skin disease caused by Coccidioides immitis or Coccidioides posadasii (C. posadasii) and is observed in certain parts of the United States, such as California, Arizona, Texas, and northern Mexico. Coccidioidomycosis is characterized by skin ulcers, abscesses, and bone lesions, and sometimes involves systemic organ dysfunction, such as inflammation of the heart and brain, which can lead to fatality. TLR2, TLR4, and Dectin-1 are responsible for eliminating Coccidioides mycosis [123]. Thus, vaccination against C. posadasii infection depends on innate sensing by Dectin-1 and Dectin-2 [124].

In the skin, IL-17 contributes to the suppression of the Coccidioides growth under certain conditions. Although IFN- $\gamma$ receptor-deficient mice show the burden of Coccidioides infection, IL-17A-depleted IFN- $\gamma$ receptor mice show significantly increased growth of C. posadasii. This indicates that IL-17 mediated immune responses are required protection against subcutaneous $C$. posadasii infection under IFN- $\gamma$-insufficient conditions. Therefore, IL-17 might play a more important role in immunity against $C$. posadasii under Th2-dominant conditions in the skin [125].

In contrast, the IL-17 mediated antimicrobial action differs in other organs. For instance, IL-17A-deficient mice exhibit partial clearance of Coccidioides from the lungs after intranasal injection [126]. IL-17 receptor A-deficient mice show sustained Coccidioides infection after immunization, which decreased their post-challenge survival [127].

\section{Conclusions}

This review summarizes the updated role of Th17 cells in antimicrobial action against cutaneous fungal infections. Almost all cutaneous fungal infections exhibit enhanced Th17 reaction in the initial phase; however, this reaction is impaired in the later phase. Although the underlying reason remains unclear, this explains the plasticity of Th17 cells under the influence of IL-23, leading to inhibition of IL-17 production and induction of IFN- $\gamma$ and/or GM-CSF production [30]. The detailed mechanism needs to be clarified, because this mechanism might contribute to intractable chronic fungal infection. Research on Candida infection is well-established and updated in the field of anti-fungal dermatology. Other fungal species also need to be studied in the same manner, because IL-17 responses for the elimination of fungi in skin infection are different for several species of fungi.

Author Contributions: Y.S. (Yu Sawada) wrote the manuscript. A.S., Y.S. (Yumiko Sakuragi), N.S.-S., and H.Y. conducted critical review of this manuscript. M.N. supervised to write this manuscript. All authors have read and agreed to the published version of the manuscript.

Funding: This research received no external funding.

Institutional Review Board Statement: Not applicable.

Informed Consent Statement: Not applicable.

Data Availability Statement: Not applicable.

Conflicts of Interest: The authors declare no conflict of interest. 


\section{References}

1. Dainichi, T.; Kitoh, A.; Otsuka, A.; Nakajima, S.; Nomura, T.; Kaplan, D.H.; Kabashima, K. The epithelial immune microenvironment (EIME) in atopic dermatitis and psoriasis. Nat. Immunol. 2018, 19, 1286-1298. [CrossRef]

2. Egawa, G.; Kabashima, K. Skin as a peripheral lymphoid organ: Revisiting the concept of skin-associated lymphoid tissues. J. Investig. Dermatol. 2011, 131, 2178-2185. [CrossRef] [PubMed]

3. Bernard, J.J.; Gallo, R.L.; Krutmann, J. Photoimmunology: How ultraviolet radiation affects the immune system. Nat. Rev. Immunol. 2019, 19, 688-701. [CrossRef] [PubMed]

4. Sakuragi, Y.; Sawada, Y.; Nakamura, M. Leukoderma following allergic contact dermatitis caused by the silicone component silprene-30A/B in swimming goggles. Contact Dermat. 2017, 77, 418-419. [CrossRef] [PubMed]

5. Honda, T.; Egawa, G.; Grabbe, S.; Kabashima, K. Update of immune events in the murine contact hypersensitivity model: Toward the understanding of allergic contact dermatitis. J. Investig. Dermatol. 2013, 133, 303-315. [CrossRef]

6. Nakatsuji, T.; Chen, T.H.; Narala, S.; Chun, K.A.; Two, A.M.; Yun, T.; Shafiq, F.; Kotol, P.F.; Bouslimani, A.; Melnik, A.V.; et al. Antimicrobials from human skin commensal bacteria protect against Staphylococcus aureus and are deficient in atopic dermatitis. Sci. Transl. Med. 2017, 9. [CrossRef]

7. Harpf, V.; Rambach, G.; Würzner, R.; Lass-Flörl, C.; Speth, C. Candida and complement: New aspects in an old battle. Front. Immunol. 2020, 11, 1471. [CrossRef]

8. Yoo, Y.J.; Kim, A.R.; Perinpanayagam, H.; Han, S.H.; Kum, K.Y. Candida albicans virulence factors and pathogenicity for endodontic infections. Microorganisms 2020, 8, 1300. [CrossRef] [PubMed]

9. Kabashima, K.; Honda, T.; Ginhoux, F.; Egawa, G. The immunological anatomy of the skin. Nat. Rev. Immunol. 2019, 19, 19-30. [CrossRef]

10. Hube, B.; Hay, R.; Brasch, J.; Veraldi, S.; Schaller, M. Dermatomycoses and inflammation: The adaptive balance between growth, damage, and survival. J. Mycol. Med. 2015, 25, e44-e58. [CrossRef]

11. Hay, R.J. Tinea capitis: Current status. Mycopathologia 2017, 182, 87-93. [CrossRef]

12. Kashem, S.W.; Kaplan, D.H. Skin immunity to Candida albicans. Trends Immunol. 2016, 37, 440-450. [CrossRef]

13. Lanternier, F.; Pathan, S.; Vincent, Q.B.; Liu, L.; Cypowyj, S.; Prando, C.; Migaud, M.; Taibi, L.; Ammar-Khodja, A.; Stambouli, O.B.; et al. Deep dermatophytosis and inherited CARD9 deficiency. N. Engl. J. Med. 2013, 369, 1704-1714. [CrossRef] [PubMed]

14. Hu, D.; Tjon, E.C.; Andersson, K.M.; Molica, G.M.; Pham, M.C.; Healy, B.; Murugaiyan, G.; Pochet, N.; Kuchroo, V.K.; Bokarewa, M.I.; et al. Aberrant expression of USF2 in refractory rheumatoid arthritis and its regulation of proinflammatory cytokines in Th17 cells. Proc. Natl. Acad. Sci. USA 2020, 117, 30639-30648. [CrossRef]

15. Saito-Sasaki, N.; Sawada, Y.; Omoto, D.; Ohmori, S.; Haruyama, S.; Yoshioka, M.; Nishio, D.; Nakamura, M. A possible pathogenetic role of IL-23/IL-17 axis in rheumatoid nodules in patients with rheumatoid arthritis. Clin. Immunol. 2016, 170, 20-21. [CrossRef]

16. Hawkes, J.E.; Chan, T.C.; Krueger, J.G. Psoriasis pathogenesis and the development of novel targeted immune therapies. J. Allergy Clin. Immunol. 2017, 140, 645-653. [CrossRef] [PubMed]

17. Almradi, A.; Hanzel, J.; Sedano, R.; Parker, C.E.; Feagan, B.G.; Ma, C.; Jairath, V. Clinical trials of IL-12/IL-23 inhibitors in inflammatory bowel disease. BioDrugs 2020, 34, 713-721. [CrossRef] [PubMed]

18. Li, B.; Huang, L.; Lv, P.; Li, X.; Liu, G.; Chen, Y.; Wang, Z.; Qian, X.; Shen, Y.; Li, Y.; et al. The role of Th17 cells in psoriasis. Immunol. Res. 2020, 68, 296-309. [CrossRef]

19. Leung, S.; Liu, X.; Fang, L.; Chen, X.; Guo, T.; Zhang, J. The cytokine milieu in the interplay of pathogenic Th1/Th17 cells and regulatory T cells in autoimmune disease. Cell. Mol. Immunol. 2010, 7, 182-189. [CrossRef]

20. Koga, C.; Kabashima, K.; Shiraishi, N.; Kobayashi, M.; Tokura, Y. Possible pathogenic role of Th17 cells for atopic dermatitis. J. Investig. Dermatol. 2008, 128, 2625-2630. [CrossRef]

21. Zheng, Y.; Danilenko, D.M.; Valdez, P.; Kasman, I.; Eastham-Anderson, J.; Wu, J.; Ouyang, W. Interleukin-22, a T(H)17 cytokine, mediates IL-23-induced dermal inflammation and acanthosis. Nature 2007, 445, 648-651. [CrossRef]

22. Cheuk, S.; Wikén, M.; Blomqvist, L.; Nylén, S.; Talme, T.; Ståhle, M.; Eidsmo, L. Epidermal Th22 and Tc17 cells form a localized disease memory in clinically healed psoriasis. J. Immunol. 2014, 192, 3111-3120. [CrossRef]

23. Ortega, C.; Fernández, A.S.; Carrillo, J.M.; Romero, P.; Molina, I.J.; Moreno, J.C.; Santamaría, M. IL-17-producing CD8+ T lymphocytes from psoriasis skin plaques are cytotoxic effector cells that secrete Th17-related cytokines. J. Leukoc. Biol. 2009, 86, 435-443. [CrossRef]

24. Hijnen, D.; Knol, E.F.; Gent, Y.Y.; Giovannone, B.; Beijn, S.J.; Kupper, T.S.; Bruijnzeel-Koomen, C.A.; Clark, R.A. CD8(+) T cells in the lesional skin of atopic dermatitis and psoriasis patients are an important source of IFN- $\gamma$, IL-13, IL-17, and IL-22. J. Investig. Dermatol. 2013, 133, 973-979. [CrossRef]

25. Yoshiki, R.; Kabashima, K.; Honda, T.; Nakamizo, S.; Sawada, Y.; Sugita, K.; Yoshioka, H.; Ohmori, S.; Malissen, B.; Tokura, Y.; et al. IL-23 from Langerhans cells is required for the development of imiquimod-induced psoriasis-like dermatitis by induction of IL-17A-producing $\gamma \delta$ T cells. J. Investig. Dermatol. 2014, 134, 1912-1921. [CrossRef] [PubMed]

26. Nakamizo, S.; Honda, T.; Adachi, A.; Nagatake, T.; Kunisawa, J.; Kitoh, A.; Otsuka, A.; Dainichi, T.; Nomura, T.; Ginhoux, F.; et al. High fat diet exacerbates murine psoriatic dermatitis by increasing the number of IL-17-producing $\gamma \delta \mathrm{T}$ cells. Sci. Rep. 2017, 7, 14076. [CrossRef] [PubMed] 
27. Saito-Sasaki, N.; Sawada, Y.; Mashima, E.; Yamaguchi, T.; Ohmori, S.; Yoshioka, H.; Haruyama, S.; Okada, E.; Nakamura, M. Maresin-1 suppresses imiquimod-induced skin inflammation by regulating IL-23 receptor expression. Sci. Rep. 2018, 8, 5522. [CrossRef] [PubMed]

28. Ueharaguchi, Y.; Honda, T.; Kusuba, N.; Hanakawa, S.; Adachi, A.; Sawada, Y.; Otsuka, A.; Kitoh, A.; Dainichi, T.; Egawa, G.; et al. Thromboxane A(2) facilitates IL-17A production from $\mathrm{V} \gamma 4(+) \gamma \delta \mathrm{T}$ cells and promotes psoriatic dermatitis in mice. J. Allergy Clin. Immunol. 2018, 142, 680-683. [CrossRef]

29. Sawada, Y.; Honda, T.; Nakamizo, S.; Otsuka, A.; Ogawa, N.; Kobayashi, Y.; Nakamura, M.; Kabashima, K. Resolvin E1 attenuates murine psoriatic dermatitis. Sci. Rep. 2018, 8, 11873. [CrossRef]

30. Stockinger, B.; Omenetti, S. The dichotomous nature of T helper 17 cells. Nat. Rev. Immunol. 2017, 17, 535-544. [CrossRef]

31. Shibue, Y.; Kimura, S.; Kajiwara, C.; Iwakura, Y.; Yamaguchi, K.; Tateda, K. Role of interleukin-17 in a murine communityassociated methicillin-resistant Staphylococcus aureus pneumonia model. Microbes Infect. 2019, 21, 33-39. [CrossRef] [PubMed]

32. Thammahong, A.; Kiatsurayanon, C.; Edwards, S.W.; Rerknimitr, P.; Chiewchengchol, D. The clinical significance of fungi in atopic dermatitis. Int. J. Dermatol. 2020, 59, 926-935. [CrossRef] [PubMed]

33. Pontón, J.; Omaetxebarría, M.J.; Elguezabal, N.; Alvarez, M.; Moragues, M.D. Immunoreactivity of the fungal cell wall. Med. Mycol. 2001, 39 (Suppl. 1), 101-110. [CrossRef]

34. Biondo, C.; Malara, A.; Costa, A.; Signorino, G.; Cardile, F.; Midiri, A.; Galbo, R.; Papasergi, S.; Domina, M.; Pugliese, M.; et al. Recognition of fungal RNA by TLR7 has a nonredundant role in host defense against experimental candidiasis. Eur. J. Immunol. 2012, 42, 2632-2643. [CrossRef] [PubMed]

35. Jepsen, C.S.; Dubey, L.K.; Colmorten, K.B.; Moeller, J.B.; Hammond, M.A.; Nielsen, O.; Schlosser, A.; Templeton, S.P.; Sorensen, G.L.; Holmskov, U. FIBCD1 binds Aspergillus fumigatus and regulates lung epithelial response to cell wall components. Front. Immunol. 2018, 9, 1967. [CrossRef]

36. Moeller, J.B.; Leonardi, I.; Schlosser, A.; Flamar, A.L.; Bessman, N.J.; Putzel, G.G.; Thomsen, T.; Hammond, M.; Jepsen, C.S.; Skjødt, K.; et al. Modulation of the fungal mycobiome is regulated by the chitin-binding receptor FIBCD1. J. Exp. Med. 2019, 216, 2689-2700. [CrossRef]

37. Haley, K.; Igyártó, B.Z.; Ortner, D.; Bobr, A.; Kashem, S.; Schenten, D.; Kaplan, D.H. Langerhans cells require MyD88-dependent signals for Candida albicans response but not for contact hypersensitivity or migration. J. Immunol. 2012, 188, 4334-4339. [CrossRef]

38. Wcisło-Dziadecka, D.; Kaźmierczak, A.; Grabarek, B.; Zbiciak-Nylec, M.; Brzezińska-Wcisło, L. Are new variants of psoriasis therapy (IL-17 inhibitors) safe? Int. J. Dermatol. 2019, 58, 1360-1365. [CrossRef]

39. Papini, M.; Natalini, Y. Candida infections in psoriatic patients on anti-IL17 therapy: A case series. J. Dermatol. Treat. 2018, 29 (Suppl. 2), 3-4. [CrossRef]

40. Peric, M.; Koglin, S.; Dombrowski, Y.; Gross, K.; Bradac, E.; Büchau, A.; Steinmeyer, A.; Zügel, U.; Ruzicka, T.; Schauber, J. Vitamin D analogs differentially control antimicrobial peptide/“alarmin" expression in psoriasis. PLoS ONE 2009, 4, e6340. [CrossRef]

41. Peric, M.; Koglin, S.; Kim, S.M.; Morizane, S.; Besch, R.; Prinz, J.C.; Ruzicka, T.; Gallo, R.L.; Schauber, J. IL-17A enhances vitamin D3-induced expression of cathelicidin antimicrobial peptide in human keratinocytes. J. Immunol. 2008, 181, 8504-8512. [CrossRef]

42. Eyerich, K.; Pennino, D.; Scarponi, C.; Foerster, S.; Nasorri, F.; Behrendt, H.; Ring, J.; Traidl-Hoffmann, C.; Albanesi, C.; Cavani, A. IL-17 in atopic eczema: Linking allergen-specific adaptive and microbial-triggered innate immune response. J. Allergy Clin. Immunol. 2009, 123, 59-66. [CrossRef]

43. Liang, S.C.; Tan, X.Y.; Luxenberg, D.P.; Karim, R.; Dunussi-Joannopoulos, K.; Collins, M.; Fouser, L.A. Interleukin (IL)-22 and IL-17 are coexpressed by Th17 cells and cooperatively enhance expression of antimicrobial peptides. J. Exp. Med. 2006, 203, 2271-2279. [CrossRef]

44. Zheng, N.X.; Wang, Y.; Hu, D.D.; Yan, L.; Jiang, Y.Y. The role of pattern recognition receptors in the innate recognition of Candida albicans. Virulence 2015, 6, 347-361. [CrossRef]

45. Sirvent, S.; Soria, I.; Cirauqui, C.; Cases, B.; Manzano, A.I.; Diez-Rivero, C.M.; Reche, P.A.; López-Relaño, J.; Martínez-Naves, E.; Cañada, F.J.; et al. Novel vaccines targeting dendritic cells by coupling allergoids to nonoxidized mannan enhance allergen uptake and induce functional regulatory T cells through programmed death ligand 1. J. Allergy Clin. Immunol. 2016, 138, 558-567. [CrossRef] [PubMed]

46. Mori, K.; Naganuma, M.; Mizuno, S.; Suzuki, H.; Kitazume, M.T.; Shimamura, K.; Chiba, S.; Sugita, A.; Matsuoka, K.; Hisamatsu, T.; et al. $\beta$-(1,3)-Glucan derived from Candida albicans induces inflammatory cytokines from macrophages and lamina propria mononuclear cells derived from patients with Crohn's disease. Intest. Res. 2018, 16, 384-392. [CrossRef]

47. Netea, M.G.; Gow, N.A.; Munro, C.A.; Bates, S.; Collins, C.; Ferwerda, G.; Hobson, R.P.; Bertram, G.; Hughes, H.B.; Jansen, T.; et al. Immune sensing of Candida albicans requires cooperative recognition of mannans and glucans by lectin and Toll-like receptors. J. Clin. Investig. 2006, 116, 1642-1650. [CrossRef]

48. Means, T.K.; Mylonakis, E.; Tampakakis, E.; Colvin, R.A.; Seung, E.; Puckett, L.; Tai, M.F.; Stewart, C.R.; Pukkila-Worley, R.; Hickman, S.E.; et al. Evolutionarily conserved recognition and innate immunity to fungal pathogens by the scavenger receptors SCARF1 and CD36. J. Exp. Med. 2009, 206, 637-653. [CrossRef] [PubMed]

49. Nguyen, T.N.Y.; Padungros, P.; Wongsrisupphakul, P.; Sa-Ard-Iam, N.; Mahanonda, R.; Matangkasombut, O.; Choo, M.K.; Ritprajak, P. Cell wall mannan of Candida krusei mediates dendritic cell apoptosis and orchestrates Th17 polarization via TLR-2/MyD88-dependent pathway. Sci. Rep. 2018, 8, 17123. [CrossRef] [PubMed] 
50. Choteau, L.; Parny, M.; François, N.; Bertin, B.; Fumery, M.; Dubuquoy, L.; Takahashi, K.; Colombel, J.F.; Jouault, T.; Poulain, D.; et al. Role of mannose-binding lectin in intestinal homeostasis and fungal elimination. Mucosal Immunol. 2016, 9, 767-776. [CrossRef] [PubMed]

51. Linden, J.R.; Kunkel, D.; Laforce-Nesbitt, S.S.; Bliss, J.M. The role of galectin-3 in phagocytosis of Candida albicans and Candida parapsilosis by human neutrophils. Cell Microbiol. 2013, 15, 1127-1142. [CrossRef]

52. Oharaseki, T.; Yokouchi, Y.; Enomoto, Y.; Sato, W.; Ishibashi, K.; Miura, N.; Ohno, N.; Takahashi, K. Recognition of alpha-mannan by dectin 2 is essential for onset of Kawasaki disease-like murine vasculitis induced by Candida albicans cell-wall polysaccharide. Mod. Rheumatol. 2020, 30, 350-357. [CrossRef] [PubMed]

53. Zhu, L.L.; Zhao, X.Q.; Jiang, C.; You, Y.; Chen, X.P.; Jiang, Y.Y.; Jia, X.M.; Lin, X. C-Type lectin receptors Dectin-3 and Dectin-2 form a heterodimeric pattern-recognition receptor for host defense against fungal infection. Immunity 2013, 39, 324-334. [CrossRef] [PubMed]

54. Cambi, A.; Netea, M.G.; Mora-Montes, H.M.; Gow, N.A.; Hato, S.V.; Lowman, D.W.; Kullberg, B.J.; Torensma, R.; Williams, D.L.; Figdor, C.G. Dendritic cell interaction with Candida albicans critically depends on N-linked mannan. J. Biol. Chem. 2008, 283, 20590-20599. [CrossRef]

55. Van de Veerdonk, F.L.; Marijnissen, R.J.; Kullberg, B.J.; Koenen, H.J.; Cheng, S.C.; Joosten, I.; van den Berg, W.B.; Williams, D.L.; van der Meer, J.W.; Joosten, L.A.; et al. The macrophage mannose receptor induces IL-17 in response to Candida albicans. Cell Host Microbe 2009, 5, 329-340. [CrossRef]

56. Miyazato, A.; Nakamura, K.; Yamamoto, N.; Mora-Montes, H.M.; Tanaka, M.; Abe, Y.; Tanno, D.; Inden, K.; Gang, X.; Ishii, K.; et al. Toll-Like receptor 9-dependent activation of myeloid dendritic cells by deoxynucleic acids from Candida albicans. Infect. Immun. 2009, 77, 3056-3064. [CrossRef] [PubMed]

57. Kashem, S.W.; Riedl, M.S.; Yao, C.; Honda, C.N.; Vulchanova, L.; Kaplan, D.H. Nociceptive sensory fibers drive interleukin23 production from $\mathrm{CD} 301 \mathrm{~b}+$ dermal dendritic cells and drive protective cutaneous immunity. Immunity 2015, 43, 515-526. [CrossRef]

58. Trautwein-Weidner, K.; Gladiator, A.; Kirchner, F.R.; Becattini, S.; Rülicke, T.; Sallusto, F.; LeibundGut-Landmann, S. Antigenspecific Th17 cells are primed by distinct and complementary dendritic cell subsets in oropharyngeal candidiasis. PLoS Pathog. 2015, 11, e1005164. [CrossRef]

59. Campois, T.G.; Zucoloto, A.Z.; de Almeida Araujo, E.J.; Svidizinski, T.I.E.; Almeida, R.S.; da Silva Quirino, G.F.; Harano, R.M.; Conchon-Costa, I.; Felipe, I. Immunological and histopathological characterization of cutaneous candidiasis. J. Med. Microbiol. 2015, 64, 810-817. [CrossRef]

60. Park, C.O.; Fu, X.; Jiang, X.; Pan, Y.; Teague, J.E.; Collins, N.; Tian, T.; O'Malley, J.T.; Emerson, R.O.; Kim, J.H.; et al. Staged development of long-lived T-cell receptor $\alpha \beta \mathrm{T}(\mathrm{H}) 17$ resident memory T-cell population to Candida albicans after skin infection. J. Allergy Clin. Immunol. 2018, 142, 647-662. [CrossRef]

61. Alves de Medeiros, A.K.; Lodewick, E.; Bogaert, D.J.; Haerynck, F.; Van Daele, S.; Lambrecht, B.; Bosma, S.; Vanderdonckt, L.; Lortholary, O.; Migaud, M.; et al. Chronic and invasive fungal infections in a family with CARD9 deficiency. J. Clin. Immunol. 2016, 36, 204-209. [CrossRef]

62. Glocker, E.O.; Hennigs, A.; Nabavi, M.; Schäffer, A.A.; Woellner, C.; Salzer, U.; Pfeifer, D.; Veelken, H.; Warnatz, K.; Tahami, F.; et al. A homozygous CARD9 mutation in a family with susceptibility to fungal infections. N. Engl. J. Med. 2009, 361, 1727-1735. [CrossRef]

63. Puel, A.; Cypowyj, S.; Bustamante, J.; Wright, J.F.; Liu, L.; Lim, H.K.; Migaud, M.; Israel, L.; Chrabieh, M.; Audry, M.; et al. Chronic mucocutaneous candidiasis in humans with inborn errors of interleukin-17 immunity. Science 2011, 332, 65-68. [CrossRef] [PubMed]

64. Kärner, J.; Pihlap, M.; Ranki, A.; Krohn, K.; Trebusak Podkrajsek, K.; Bratanic, N.; Battelino, T.; Willcox, N.; Peterson, P.; Kisand, K. IL-6-Specific autoantibodies among APECED and thymoma patients. Immun. Inflamm. Dis. 2016, 4, 235-243. [CrossRef]

65. Ling, Y.; Cypowyj, S.; Aytekin, C.; Galicchio, M.; Camcioglu, Y.; Nepesov, S.; Ikinciogullari, A.; Dogu, F.; Belkadi, A.; Levy, R.; et al. Inherited IL-17RC deficiency in patients with chronic mucocutaneous candidiasis. J. Exp. Med. 2015, 212, 619-631. [CrossRef] [PubMed]

66. Nielsen, J.; Kofod-Olsen, E.; Spaun, E.; Larsen, C.S.; Christiansen, M.; Mogensen, T.H. A STAT1-gain-of-function mutation causing Th17 deficiency with chronic mucocutaneous candidiasis, psoriasiform hyperkeratosis and dermatophytosis. BMJ Case Rep. 2015, 2015. [CrossRef] [PubMed]

67. Van de Veerdonk, F.L.; Plantinga, T.S.; Hoischen, A.; Smeekens, S.P.; Joosten, L.A.; Gilissen, C.; Arts, P.; Rosentul, D.C.; Carmichael, A.J.; Smits-van der Graaf, C.A.; et al. STAT1 mutations in autosomal dominant chronic mucocutaneous candidiasis. N. Engl. J. Med. 2011, 365, 54-61. [CrossRef] [PubMed]

68. Abusleme, L.; Diaz, P.I.; Freeman, A.F.; Greenwell-Wild, T.; Brenchley, L.; Desai, J.V.; Ng, W.I.; Holland, S.M.; Lionakis, M.S.; Segre, J.A.; et al. Human defects in STAT3 promote oral mucosal fungal and bacterial dysbiosis. JCI Insight 2018, 3 , e122061. [CrossRef] [PubMed]

69. Dahl, M.V. Dermatophytosis and the immune response. J. Am. Acad. Dermatol. 1994, 31, S34-S41. [CrossRef]

70. Dahl, M.V.; Grando, S.A. Chronic dermatophytosis: What is special about Trichophyton rubrum? Adv. Dermatol. 1994, 9, 97-109. 
71. Sakuragi, Y.; Sawada, Y.; Hara, Y.; Ohmori, S.; Omoto, D.; Haruyama, S.; Yoshioka, M.; Nishio, D.; Nakamura, M. Increased circulating Th17 cell in a patient with tinea capitis caused by Microsporum canis. Allergol. Int. Off. J. Jpn. Soc. Allergol. 2016, 65, 215-216. [CrossRef]

72. Goto, Y.; Suzuki, T.; Suzuki, Y.; Anzawa, K.; Mochizuki, T.; Tamura, T.; Makimura, K.; Aoshima, M.; Ito, T.; Tokura, Y. Trichophyton tonsurans-induced kerion celsi with decreased defensin expression and paradoxically increased interleukin-17A production. J. Dermatol. 2019, 46, 794-797. [CrossRef]

73. Tokura, Y.; Sawada, Y.; Shimauchi, T. Skin manifestations of adult T-cell leukemia/lymphoma: Clinical, cytological and immunological features. J. Dermatol. 2014, 41, 19-25. [CrossRef]

74. Sawada, Y.; Nakamura, M.; Kabashima-Kubo, R.; Shimauchi, T.; Kobayashi, M.; Tokura, Y. Defective epidermal innate immunity and resultant superficial dermatophytosis in adult T-cell leukemia/lymphoma. Clin. Cancer Res. 2012, 18, 3772-3779. [CrossRef] [PubMed]

75. Sawada, Y.; Nakamura, M.; Kabashima-Kubo, R.; Shimauchi, T.; Kobayashi, M.; Tokura, Y. Defective epidermal induction of S100A7/psoriasin associated with low frequencies of skin-infiltrating Th17 cells in dermatophytosis-prone adult T cell leukemia/lymphoma. Clin. Immunol. 2013, 148, 1-3. [CrossRef] [PubMed]

76. Burstein, V.L.; Guasconi, L.; Beccacece, I.; Theumer, M.G.; Mena, C.; Prinz, I.; Cervi, L.; Herrero, M.; Masih, D.T.; Chiapello, L.S. IL-17-Mediated immunity controls skin infection and Thelper 1 response during experimental Microsporum canis dermatophytosis. J. Investig. Dermatol. 2018, 138, 1744-1753. [CrossRef] [PubMed]

77. Yoshikawa, F.S.; Yabe, R.; Iwakura, Y.; de Almeida, S.R.; Saijo, S. Dectin-1 and Dectin-2 promote control of the fungal pathogen Trichophyton rubrum independently of IL-17 and adaptive immunity in experimental deep dermatophytosis. Innate Immun. 2016, 22, 316-324. [CrossRef] [PubMed]

78. Yoshikawa, F.S.; Ferreira, L.G.; de Almeida, S.R. IL-1 signaling inhibits Trichophyton rubrum conidia development and modulates the IL-17 response in vivo. Virulence 2015, 6, 449-457. [CrossRef] [PubMed]

79. Stalhberger, T.; Simenel, C.; Clavaud, C.; Eijsink, V.G.; Jourdain, R.; Delepierre, M.; Latgé, J.P.; Breton, L.; Fontaine, T. Chemical organization of the cell wall polysaccharide core of Malassezia restricta. J. Biol. Chem. 2014, 289, 12647-12656. [CrossRef] [PubMed]

80. Baroni, A.; Orlando, M.; Donnarumma, G.; Farro, P.; Iovene, M.R.; Tufano, M.A.; Buommino, E. Toll-Like receptor 2 (TLR2) mediates intracellular signalling in human keratinocytes in response to Malassezia furfur. Arch. Dermatol. Res. 2006, 297, 280-288. [CrossRef] [PubMed]

81. Roesner, L.M.; Ernst, M.; Chen, W.; Begemann, G.; Kienlin, P.; Raulf, M.K.; Lepenies, B.; Werfel, T. Human thioredoxin, a damage-associated molecular pattern and Malassezia-crossreactive autoallergen, modulates immune responses via the C-type lectin receptors Dectin-1 and Dectin-2. Sci. Rep. 2019, 9, 11210. [CrossRef]

82. Haider, M.; Dambuza, I.M.; Asamaphan, P.; Stappers, M.; Reid, D.; Yamasaki, S.; Brown, G.D.; Gow, N.A.R.; Erwig, L.P. The pattern recognition receptors dectin-2, mincle, and $\mathrm{FcR}_{\mathrm{C}}$ impact the dynamics of phagocytosis of Candida, Saccharomyces, Malassezia, and Mucor species. PLoS ONE 2019, 14, e0220867. [CrossRef]

83. Wollenberg, A.; Mommaas, M.; Oppel, T.; Schottdorf, E.M.; Günther, S.; Moderer, M. Expression and function of the mannose receptor CD206 on epidermal dendritic cells in inflammatory skin diseases. J. Investig. Dermatol. 2002, 118, 327-334. [CrossRef] [PubMed]

84. Kasperkovitz, P.V.; Khan, N.S.; Tam, J.M.; Mansour, M.K.; Davids, P.J.; Vyas, J.M. Toll-Like receptor 9 modulates macrophage antifungal effector function during innate recognition of Candida albicans and Saccharomyces cerevisiae. Infect. Immun. 2011, 79, 4858-4867. [CrossRef]

85. Balaji, H.; Heratizadeh, A.; Wichmann, K.; Niebuhr, M.; Crameri, R.; Scheynius, A.; Werfel, T. Malassezia sympodialis thioredoxinspecific T cells are highly cross-reactive to human thioredoxin in atopic dermatitis. J. Allergy Clin. Immunol. 2011, 128, 92-99. [CrossRef]

86. Sato, Y.; Fujimura, T.; Tanita, K.; Chunbing, L.; Matsushita, S.; Fujisawa, Y.; Otsuka, A.; Yamamoto, Y.; Hidaka, T.; Aiba, S. Malassezia-Derived aryl hydrocarbon receptor ligands enhance the CCL20/Th17/soluble CD163 pathogenic axis in extramammary Paget's disease. Exp. Dermatol. 2019, 28, 933-939. [CrossRef]

87. Sparber, F.; De Gregorio, C.; Steckholzer, S.; Ferreira, F.M.; Dolowschiak, T.; Ruchti, F.; Kirchner, F.R.; Mertens, S.; Prinz, I.; Joller, N.; et al. The skin commensal yeast Malassezia triggers a type 17 response that coordinates anti-fungal immunity and exacerbates skin inflammation. Cell Host Microbe 2019, 25, 389-403. [CrossRef]

88. Sizar, O.; Talati, R. Sporotrichosis. In StatPearls; StatPearls Publishing Copyright; StatPearls Publishing LLC.: Treasure Island, FL, USA, 2020.

89. Chakrabarti, A.; Bonifaz, A.; Gutierrez-Galhardo, M.C.; Mochizuki, T.; Li, S. Global epidemiology of sporotrichosis. Med. Mycol. 2015, 53, 3-14. [CrossRef] [PubMed]

90. Coles, F.B.; Schuchat, A.; Hibbs, J.R.; Kondracki, S.F.; Salkin, I.F.; Dixon, D.M.; Chang, H.G.; Duncan, R.A.; Hurd, N.J.; Morse, D.L. A multistate outbreak of sporotrichosis associated with sphagnum moss. Am. J. Epidemiol. 1992, 136, 475-487. [CrossRef] [PubMed]

91. Jellmayer, J.A.; Ferreira, L.S.; Manente, F.A.; Gonçalves, A.C.; Polesi, M.C.; Batista-Duharte, A.; Carlos, I.Z. Dectin-1 expression by macrophages and related antifungal mechanisms in a murine model of Sporothrix schenckii sensu stricto systemic infection. Microb. Pathog. 2017, 110, 78-84. [CrossRef] 
92. Sassá, M.F.; Saturi, A.E.; Souza, L.F.; Ribeiro, L.C.; Sgarbi, D.B.; Carlos, I.Z. Response of macrophage Toll-like receptor 4 to a Sporothrix schenckii lipid extract during experimental sporotrichosis. Immunology 2009, 128, 301-309. [CrossRef]

93. Li, M.; Chen, Q.; Sun, J.; Shen, Y.; Liu, W. Inflammatory response of human keratinocytes triggered by Sporothrix schenckii via Toll-like receptor 2 and 4. J. Dermatol. Sci. 2012, 66, 80-82. [CrossRef]

94. García-Lozano, A.; Toriello, C.; Antonio-Herrera, L.; Bonifaz, L.C. Sporothrix schenckii Immunization, but not infection, induces protective Th17 responses mediated by circulating memory CD4(+) T cells. Front. Microbiol. 2018, 9, 1275. [CrossRef]

95. Zhang, X.; Zhang, J.; Huang, H.; Xue, R.; Hu, X.; Li, M.; Zhong, Y.; Yuan, L. Taenia taeniaeformis in rat favors protracted skin lesions caused by Sporothrix schenckii infection: Dectin-1 and IL-17 are dispensable for clearance of this fungus. PLoS ONE 2012, 7, e52514. [CrossRef]

96. Ferreira, L.S.; Gonçalves, A.C.; Portuondo, D.L.; Maia, D.C.; Placeres, M.C.; Batista-Duharte, A.; Carlos, I.Z. Optimal clearance of Sporothrix schenckii requires an intact Th17 response in a mouse model of systemic infection. Immunobiology 2015, 220, 985-992. [CrossRef] [PubMed]

97. Gonçalves, A.C.; Ferreira, L.S.; Manente, F.A.; de Faria, C.; Polesi, M.C.; de Andrade, C.R.; Zamboni, D.S.; Carlos, I.Z. The NLRP3 inflammasome contributes to host protection during Sporothrix schenckii infection. Immunology 2017, 151, 154-166. [CrossRef] [PubMed]

98. Negrini, T.D.C.; Ferreira, L.S.; Arthur, R.A.; Alegranci, P.; Placeres, M.C.; Spolidorio, L.C.; Carlos, I.Z. Influence of TLR-2 in the immune response in the infection induced by fungus Sporothrix schenckii. Immunol. Investig. 2014, 43, 370-390. [CrossRef] [PubMed]

99. Breda, L.C.D.; Breda, C.N.S.; de Almeida, J.R.F.; Paulo, L.N.M.; Jannuzzi, G.P.; Menezes, I.G.; Albuquerque, R.C.; Câmara, N.O.S.; Ferreira, K.S.; de Almeida, S.R. Fonsecaea pedrosoi conidia and hyphae activate neutrophils distinctly: Requirement of TLR-2 and TLR-4 in neutrophil effector functions. Front. Immunol. 2020, 11, 540064. [CrossRef] [PubMed]

100. De Castro, R.J.A.; Siqueira, I.M.; Jerônimo, M.S.; Basso, A.M.M.; Veloso Junior, P.H.H.; Magalhães, K.G.; Leonhardt, L.C.; de Oliveira, S.A.M.; Bürgel, P.H.; Tavares, A.H.; et al. The major Chromoblastomycosis etiologic agent Fonsecaea pedrosoi activates the NLRP3 inflammasome. Front. Immunol. 2017, 8, 1572. [CrossRef] [PubMed]

101. Wevers, B.A.; Kaptein, T.M.; Zijlstra-Willems, E.M.; Theelen, B.; Boekhout, T.; Geijtenbeek, T.B.; Gringhuis, S.I. Fungal engagement of the C-type lectin mincle suppresses dectin-1-induced antifungal immunity. Cell Host Microbe 2014, 15, 494-505. [CrossRef] [PubMed]

102. Siqueira, I.M.; Wüthrich, M.; Li, M.; Wang, H.; Las-Casas, L.O.; de Castro, R.J.A.; Klein, B.; Bocca, A.L. Early immune response against Fonsecaea pedrosoi requires Dectin-2-mediated Th17 activity, whereas Th1 response, aided by Treg cells, is crucial for fungal clearance in later stage of experimental chromoblastomycosis. PLoS Negl. Trop. Dis. 2020, 14, e0008386. [CrossRef]

103. Dong, B.; Tong, Z.; Li, R.; Chen, S.C.; Liu, W.; Liu, W.; Chen, Y.; Zhang, X.; Duan, Y.; Li, D.; et al. Transformation of Fonsecaea pedrosoi into sclerotic cells links to the refractoriness of experimental chromoblastomycosis in BALB/c mice via a mechanism involving a chitin-induced impairment of IFN- $\gamma$ production. PLoS Negl. Trop. Dis. 2018, 12, e0006237. [CrossRef] [PubMed]

104. Silva, A.A.; Criado, P.R.; Nunes, R.S.; da Silva, W.L.; Kanashiro-Galo, L.; Duarte, M.I.; Sotto, M.N.; Pagliari, C. In situ immune response in human chromoblastomycosis-A possible role for regulatory and Th17 T cells. PLoS Negl. Trop. Dis. 2014, 8, e3162. [CrossRef] [PubMed]

105. Dong, B.; Li, D.; Li, R.; Chen, S.C.; Liu, W.; Liu, W.; Chen, L.; Chen, Y.; Zhang, X.; Tong, Z.; et al. A chitin-like component on sclerotic cells of Fonsecaea pedrosoi inhibits Dectin-1-mediated murine Th17 development by masking $\beta$-glucans. PLoS ONE 2014, 9, e114113. [CrossRef]

106. Sousa Mda, G.; Reid, D.M.; Schweighoffer, E.; Tybulewicz, V.; Ruland, J.; Langhorne, J.; Yamasaki, S.; Taylor, P.R.; Almeida, S.R.; Brown, G.D. Restoration of pattern recognition receptor costimulation to treat chromoblastomycosis, a chronic fungal infection of the skin. Cell Host Microbe 2011, 9, 436-443. [CrossRef]

107. Figueiredo, R.T.; Bittencourt, V.C.; Lopes, L.C.; Sassaki, G.; Barreto-Bergter, E. Toll-Like receptors (TLR2 and TLR4) recognize polysaccharides of Pseudallescheria boydii cell wall. Carbohydr. Res. 2012, 356, 260-264. [CrossRef]

108. Figueiredo, R.T.; Fernandez, P.L.; Dutra, F.F.; González, Y.; Lopes, L.C.; Bittencourt, V.C.; Sassaki, G.L.; Barreto-Bergter, E.; Bozza, M.T. TLR4 recognizes Pseudallescheria boydii conidia and purified rhamnomannans. J. Biol. Chem. 2010, 285, 40714-40723. [CrossRef]

109. Leeyaphan, C.; Hau, C.; Takeoka, S.; Tada, Y.; Bunyaratavej, S.; Pattanaprichakul, P.; Sitthinamsuwan, P.; Chaiprasert, A.; Sasajima, Y.; Makimura, K.; et al. Immune response in human chromoblastomycosis and eumycetoma-focusing on human interleukin-17A, interferon-gamma, tumour necrosis factor-alpha, interleukin-1 beta and human beta-defensin-2. Mycoses 2016, 59, 751-756. [CrossRef] [PubMed]

110. Vieira, I.R.; Fernandes, R.K.; Rodrigues, D.R.; Gorgulho, C.M.; Kaneno, R.; Soares, Â.M.V.C. TLR9 stimulation induces increase in fungicidal activity of human dendritic cells challenged with Paracoccidioides brasiliensis. Med. Mycol. 2018, 56, 911-915. [CrossRef] [PubMed]

111. Freitas, M.S.; Oliveira, A.F.; da Silva, T.A.; Fernandes, F.F.; Gonçales, R.A.; Almeida, F.; Roque-Barreira, M.C. Paracoccin induces M1 polarization of macrophages via interaction with TLR4. Front. Microbiol. 2016, 7, 1003. [CrossRef]

112. Rodriguez-Echeverri, C.; Puerta-Arias, J.D.; González, Á. Paracoccidioides brasiliensis activates mesenchymal stem cells through TLR2, TLR4, and Dectin-1. Med. Mycol. 2020, 59, 149-157. [CrossRef] [PubMed] 
113. Peres da Silva, R.; Heiss, C.; Black, I.; Azadi, P.; Gerlach, J.Q.; Travassos, L.R.; Joshi, L.; Kilcoyne, M.; Puccia, R. Extracellular vesicles from Paracoccidioides pathogenic species transport polysaccharide and expose ligands for DC-SIGN receptors. Sci. Rep. 2015, 5, 14213. [CrossRef]

114. Ruas, L.P.; Bernardes, E.S.; Fermino, M.L.; de Oliveira, L.L.; Hsu, D.K.; Liu, F.T.; Chammas, R.; Roque-Barreira, M.C. Lack of galectin-3 drives response to Paracoccidioides brasiliensis toward a Th2-biased immunity. PLoS ONE 2009, 4, e4519. [CrossRef]

115. Loures, F.V.; Araújo, E.F.; Feriotti, C.; Bazan, S.B.; Calich, V.L. TLR-4 cooperates with Dectin-1 and mannose receptor to expand Th17 and Tc17 cells induced by Paracoccidioides brasiliensis stimulated dendritic cells. Front. Microbiol. 2015, 6, 261. [CrossRef]

116. De Castro, L.F.; Longhi, L.N.A.; Paião, M.R.; Justo-Júnior, A.D.S.; de Jesus, M.B.; Blotta, M.; Mamoni, R.L. NLRP3 inflammasome is involved in the recognition of Paracoccidioides brasiliensis by human dendritic cells and in the induction of Th17 cells. J. Infect. 2018, 77, 137-144. [CrossRef]

117. Ketelut-Carneiro, N.; Souza, C.O.S.; Benevides, L.; Gardinassi, L.G.; Silva, M.C.; Tavares, L.A.; Zamboni, D.S.; Silva, J.S. Caspase-11-Dependent IL-1 $\alpha$ release boosts Th17 immunity against Paracoccidioides brasiliensis. PLoS Pathog. 2019, 15, e1007990. [CrossRef]

118. De Araújo, E.F.; Feriotti, C.; Galdino, N.A.L.; Preite, N.W.; Calich, V.L.G.; Loures, F.V. The IDO-AhR axis controls Th17/Treg immunity in a pulmonary model of fungal infection. Front. Immunol. 2017, 8, 880. [CrossRef]

119. Pagliari, C.; Fernandes, E.R.; Stegun, F.W.; da Silva, W.L.; Seixas Duarte, M.I.; Sotto, M.N. Paracoccidioidomycosis: Cells expressing IL17 and Foxp3 in cutaneous and mucosal lesions. Microb. Pathog. 2011, 50, 263-267. [CrossRef] [PubMed]

120. Loures, F.V.; Pina, A.; Felonato, M.; Feriotti, C.; de Araújo, E.F.; Calich, V.L. MyD88 signaling is required for efficient innate and adaptive immune responses to Paracoccidioides brasiliensis infection. Infect. Immun. 2011, 79, 2470-2480. [CrossRef] [PubMed]

121. Loures, F.V.; Araújo, E.F.; Feriotti, C.; Bazan, S.B.; Costa, T.A.; Brown, G.D.; Calich, V.L. Dectin-1 induces M1 macrophages and prominent expansion of CD8+IL-17+ cells in pulmonary paracoccidioidomycosis. J. Infect. Dis. 2014, 210, 762-773. [CrossRef] [PubMed]

122. Feriotti, C.; de Araújo, E.F.; Loures, F.V.; da Costa, T.A.; Galdino, N.A.L.; Zamboni, D.S.; Calich, V.L.G. NOD-Like receptor P3 inflammasome controls protective Th1/Th17 immunity against pulmonary paracoccidioidomycosis. Front. Immunol. 2017, 8, 786. [CrossRef] [PubMed]

123. Awasthi, S. Susceptibility of TLR4-defective C3H/HeJ mice to Coccidioides posadasii infection. Med. Mycol. 2010, 48, 470-475. [CrossRef] [PubMed]

124. Wang, H.; LeBert, V.; Hung, C.Y.; Galles, K.; Saijo, S.; Lin, X.; Cole, G.T.; Klein, B.S.; Wüthrich, M. C-Type lectin receptors differentially induce th17 cells and vaccine immunity to the endemic mycosis of North America. J. Immunol. 2014, 192, 1107-1119. [CrossRef] [PubMed]

125. Hung, C.Y.; Castro-Lopez, N.; Cole, G.T. Card9- and MyD88-mediated gamma interferon and nitric oxide production is essential for resistance to subcutaneous Coccidioides posadasii infection. Infect. Immun. 2016, 84, 1166-1175. [CrossRef] [PubMed]

126. Wüthrich, M.; Gern, B.; Hung, C.Y.; Ersland, K.; Rocco, N.; Pick-Jacobs, J.; Galles, K.; Filutowicz, H.; Warner, T.; Evans, M.; et al. Vaccine-Induced protection against 3 systemic mycoses endemic to North America requires Th17 cells in mice. J. Clin. Investig. 2011, 121, 554-568. [CrossRef]

127. Hung, C.Y.; Gonzalez, A.; Wüthrich, M.; Klein, B.S.; Cole, G.T. Vaccine immunity to coccidioidomycosis occurs by early activation of three signal pathways of T helper cell response (Th1, Th2, and Th17). Infect. Immun. 2011, 79, 4511-4522. [CrossRef] [PubMed] 